\title{
Periosteal Chondroma of the Rib: An Unusual Location
}

\author{
Kostal Bölgede Seyrek Rastlanılan Periosteal Kondrom \\ Cumhur Murat Tulay', Sadık Yaldız', Peyker Temiz ${ }^{2}$
}

\section{Abstract}

Periosteal chondroma is a rare, benign tumor of hyaline cartilage. Periosteal chondroma is commonly found in the metaphysis of long bones or the small, tubular bones of the hands and feet. Periosteal chondroma arising in the rib is an extremely rare event. Described is the case of a 55-year-old patient with periosteal chondroma of the rib found after more than 3 years of thoracic pain.

Key words: Periosteal chondroma, thoracic pain, chondroma.

\section{Özet}

Periosteal kondrom, hiyalin kıkırdağın nadir karşılaşılan iyi huylu tümörüdür. Periosteal kondromlar, en sık uzun kemiklerin metafiz kısmında, el ve ayakların kısa tübüler kemiklerinde yer alır. Bu tümörün kosta yerleşimine literatürde çok az rastlanmaktadır. Biz burada, 55 yaşında, üç yıldan uzun süredir göğüs ağrısı ve şişliği olan ve rezeksiyonun patolojik sonucu periosteal kondrom gelen olguyu sunuyoruz.

Anahtar Sözcükler: Periosteal kondrom, göğüs ağrısı, kondrom.
Periosteal chondroma is a benign tumor accounting for less than $2 \%$ of all chondromas (1). It is a very rare finding, especially in the rib region $(2,3)$. To the best of our knowledge, periosteal chondroma arising in the rib has been reported only 13 times in The Web of Science (1-6).

\section{CASE}

A 55-year-old female patient presented at the thoracic surgery clinic because of anterior chest wall pain ongoing for more than 3 years. On physical examination, a hard, $3 \times 4-\mathrm{cm}$ mass was palpated over the fifth rib, without skin adhesion. Computed tomography (CT) demonstrated a homogeneous tumor with clear margins and without cortical defect of the fifth rib. The tumor protruded into the subcutaneous tissue. Whole body bone scintigraphy revealed a soft tissue-originated mass located on anterior part of fifth rib (Figure 1). Surgery disclosed a tumor that was well circumscribed without invasion of the muscle or subcutaneous tissue (Figure 2). The tumor was sent for frozen section examination, which confirmed a diagnosis of benign chondroma without sign of mitosis. The fifth rib was not resected since the costal surface of the resected periosteal membrane was free of tumor. A regular, lobulated, chondroid tumor that had originated from the

\footnotetext{
'Department of Thoracic Surgey, Manisa Celal Bayar University, School of Medicine, Manisa, Turkey

${ }^{2}$ Department of Pathology, Manisa Celal Bayar University, School 'Manisa Celal Bayar Üniversitesi Tıp Fakültesi, Göğüs Cerrahi Anabilim Dalı, Manisa of Medicine, Manisa, Turkey

${ }^{2}$ Manisa Celal Bayar Üniversitesi Tıp Fakültesi, Patoloji Anabilim Dalı, Manisa
}

Submitted (Başvuru tarihi): 30.06.2017 Accepted (Kabul tarihi): 26.07.2017

Correspondence (iletişim): Cumhur Murat Tulay, Department of Thoracic Surgey, Manisa Celal Bayar University, School of Medicine, Manisa, Turkey

e-mail: cumhurtulay@hotmail.com 
periosteum was observed on pathological examination, with chondrocytes and areas of degeneration (Figure 3). The patient was discharged from the hospital the day after surgery. There has been no sign of recurrence in the 15 months since the surgery.

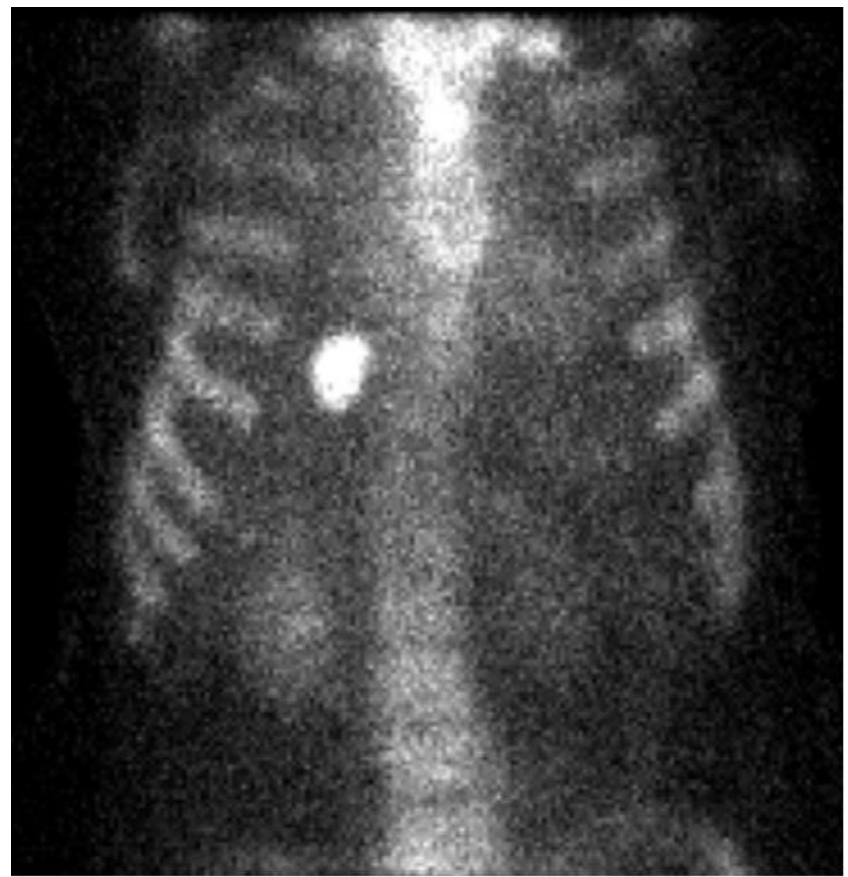

Figure 1: Bone scintigraphy demonstrating a soft-tissue originating mass located on the anterior part of the fifth rib

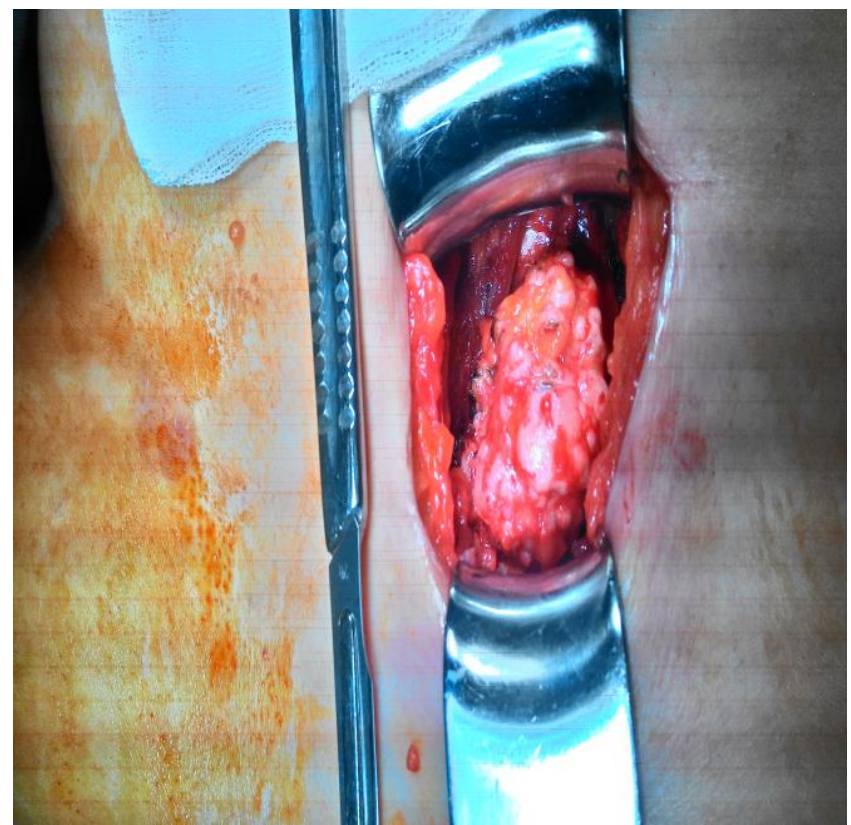

Figure 2: Intraoperative tumor with appearance resembling popcorn calcifications

\section{DISCUSSION}

Periosteal chondroma develops in the periosteal region. It is a slow-growing, benign, cartilaginous lesion characterized by a typical location on the metaphyseal cortex of both the long and short tubular bones. It does not usually extend into the medullary cavity (3). In our case, the lesion originated solely from the periosteal membrane without invasion of the rib.

Benign chondroid lesions occur most commonly in the metaphyseal regions of the femur, humerus, and phalanges (4). The rib is an extremely rare location $(1,3)$. Although chondromas are the most common benign tumors of the chest wall, periosteal chondroma of the rib is exceptionally rare. Periosteal chondroma arises from the periosteum and grows in and under the periosteum and above the cortical bone (3). It can occur both in adults and children, though it is most often observed in patients younger than 30 years, with the highest frequency in the second decade (1). Our patient was 55 years old.

It is sometimes difficult to distinguish chondroma from chondrosarcoma. Chondroma has a slow growth pattern, a mild biological course, and a regular, lobulation structure. The fibrous capsule of chondroma has few blood vessels and low cellularity. Chondrosarcoma, in contrast, has a fast growth pattern and produces an irregular, asymmetrical lobulation pattern. The chondrosarcoma capsule also has more blood vessels and active blast cells (5).

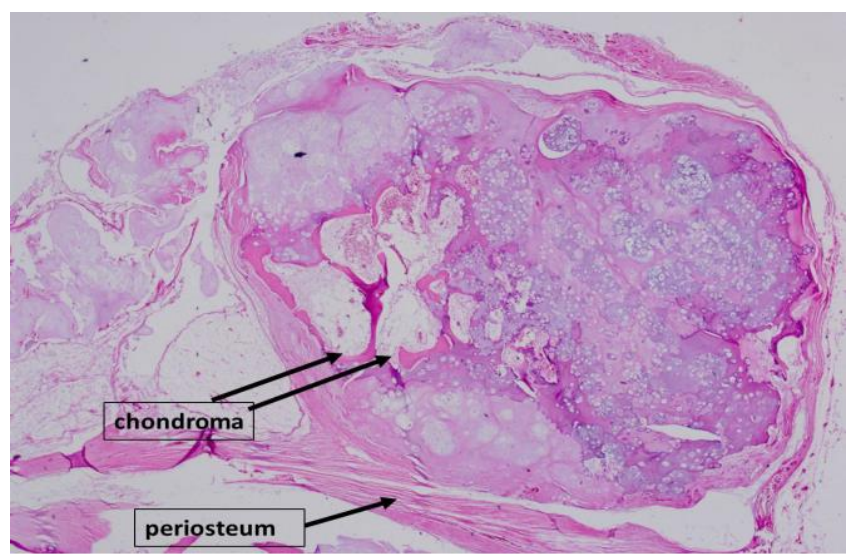

Figure 3: Periosteum-related chondroid tumor, periosteal chondroma (hematoxylin \& eosin, x20)

Although it is sometimes difficult to cut bone tissue for frozen sections, almost all bone tumors have suitable areas for analysis $(7,8)$. Frozen sections are important to distinguish malignant from benign lesions. Intraoperative tissue diagnosis provides an assessment of the adequacy of the surgical resection limits (9). Although en bloc resection may be a more effective treatment strategy, marginal excision and curettage are preferable options if the diagnosis is certain prior to surgery (6). We preferred excision of the lesion with the periosteal layer of the rib. On macroscopic examination, the underlying rib was 
complete and the periosteal membrane was dissected and excised easily. The patient has been in follow-up for 15 months without recurrence.

In conclusion, with thorough identification in the pre- and intraoperative periods, cartilage-originating thoracic wall pathologies can be completely resected.

\section{CONFLICTS OF INTEREST}

None declared.

\section{AUTHOR CONTRIBUTIONS}

Concept - C.M.T., S.Y., P.T.; Planning and Design C.M.T., S.Y., P.T.; Supervision - C.M.T., S.Y., P.T.; Funding - C.M.T., S.Y., P.T.; Materials - C.M.T., S.Y., P.T.; Data Collection and/or Processing - C.M.T., S.Y., P.T.; Analysis and/or Interpretation - C.M.T., S.Y., P.T.; Literature Review - C.M.T., S.Y., P.T.; Writing - C.M.T., S.Y., P.T.; Critical Review - C.M.T., S.Y., P.T.

\section{YAZAR KATKILARI}

Fikir - C.M.T., S.Y., P.T.; Tasarım ve Dizayn - C.M.T., S.Y., P.T.; Denetleme - C.M.T., S.Y., P.T.; Kaynaklar C.M.T., S.Y., P.T.; Malzemeler - C.M.T., S.Y., P.T.; Veri Toplama ve/veya İşleme - C.M.T., S.Y., P.T.; Analiz ve/veya Yorum - C.M.T., S.Y., P.T.; Literatür Taraması C.M.T., S.Y., P.T.; Yazıyı Yazan - C.M.T., S.Y., P.T.; Eleştirel İnceleme - C.M.T., S.Y., P.T.

\section{REFERENCES}

1. Karabakhtsian R, Heller D, Hameed M, Bethel C. Periosteal chondroma of the rib-report of a case and literature review. J Pediatr Surg 2005; 40:1505-7. [CrossRef]
2. Matsushima K, Matsuura K, Kayo M, Gushimiyagi M. Periosteal chondroma of the rib possibly associated with hemothorax: a case report. J Pediatr Surg 2006; 41 : E31-3. [CrossRef]

3. Inove S, Fujino S, Kontani K, Sawai S, Tezuka N, Hanaoka J. Periosteal chondroma of the rib: report of two cases. Surg Today 2001; 31:1074-8. [CrossRefl

4. Robinson P, White LM, Sundaram M, Kandel R, Wunder J, McDonald DJ, et al. Periosteal chondroid tumors: radiologic evaluation with pathologic correlation. Am J Roentgenol 2001; 177:1 183-8. [CrossRef]

5. Shariat Torbaghan S, Ashouri M, Jalayer Naderi N, Baherini N. Histopathologic differentiation between enchondroma and well- differentiated chondrosarcoma: evaluating the efficacy of diagnostic histologic structures. J Dent Res Dent Clin Dent Prospect 2011 ; 5:98-101.

6. Zheng $K, Y \cup X, X \cup S, X \cup M$. Periosteal chondroma of the femur: A case report and review of the literature. Oncol Lett 2015; 9:1637-40. [CrossRef]

7. Aszódi K, Glauber, A, Csató Z. The importance of rapid, intraoperative histological diagnosis in the radical surgical treatment of malignant tumours of the limbs. Arch Orth Traum Surg 1980; 96:123-30.

8. Simon MA, Biermann JS. Biopsy of bone and soft-tissue lesions. J Bone Joint Surg Am 1993; 75:616-21. [CrossRef]

9. Bhaker P, Mohan H, Handa U, Kumar S. Role of Intraoperative pathology consultation in skeletal tumors and tumor-like lesions. Sarcoma 2014; 2014:902104. [CrossRef] 